Canadian Journal of Plant Science Revue canadienne de phytotechnie

\title{
AAC Y012 and AAC Y015 yellow dry bean
}

\begin{tabular}{|r|l|}
\hline Journal: & Canadian Journal of Plant Science \\
\hline Manuscript ID & CJPS-2016-0245.R1 \\
\hline Manuscript Type: & Cultivar description \\
\hline Date Submitted by the Author: & $14-$ Sep-2016 \\
\hline Complete List of Authors: & $\begin{array}{l}\text { Balasubramanian, Parthiba; Agriculture and Agri-Food Canada, } \\
\text { Chatterton, Syama; Agriculture and Agri-Food Canada, } \\
\text { Conner, Robert; Agriculture and Agri-Food Canada, Research }\end{array}$ \\
\hline Keywords: & Yellow dry bean, high yield, large seed size, seed colour \\
\hline
\end{tabular}

\section{SCHOLARONE ${ }^{\mathrm{m}}$}

Manuscripts 
Balasubramanian et al. - AAC Y012 and AAC Y015 yellow dry bean

\author{
CULTIVAR DESCRIPTION
}

\title{
AAC Y012 and AAC Y015 yellow dry bean
}

P. M. Balasubramanian ${ }^{1,3}$, S. Chatterton ${ }^{1}$, and R. L. Conner ${ }^{2}$

${ }^{1}$ Agriculture and Agri-Food Canada, Lethbridge Research and Development Centre, P.O. Box 3000, Lethbridge, Alberta, Canada TIJ 4B1; ${ }^{2}$ Agriculture and Agri-Food Canada, Morden Research and Development Centre, Unit 101 Route 100, Morden, Manitoba, Canada R6M 1Y5; received , accepted

${ }^{3}$ To whom correspondence should be addressed.E-mail: parthiba.balasubramanian@agr.gc.ca 
Balasubramanian et al. - AAC Y012 and AAC Y015 yellow dry bean

Balasubramanian, P., Chatterton, S., and Conner, R. L. 2016. AAC Y012 and AAC Y015

yellow dry bean. Can. J. Plant Sci. 96: xxx-Xxx. AAC Y012 and AAC Y015 are high yielding, early maturing yellow dry bean (Phaseolus vulgaris L.) cultivars with a determinate bush growth habit (Type I), improved seed coat colour, and partial field resistance to white mould. AAC Y012 and AAC Y015 were developed at the Agriculture and Agri-Food Canada (AAFC) Research and Development Centre, Lethbridge, AB. AAC Y012 and AAC Y015 are suitable for irrigated wide row production in Alberta and Saskatchewan.

Key words: Yellow dry bean, high yield, large seed size, seed colour

AAC Y012 and AAC Y015 are yellow dry bean (Phaseolus vulgaris L.) cultivars with an upright, determinate bush growth habit, high yield potential, early maturity, improved seed coat colour, and partial field resistance (avoidance) to white mould caused by Sclerotinia sclerotiorum (Lib.) de Bary. They were developed at the Agriculture and Agri-Food Canada (AAFC) Research and Development Centre, Lethbridge, AB. AAC Y012 and AAC Y015 were tested in the Short Season Wide Row Irrigated Dry Bean Cooperative Registration Trials in Alberta and Saskatchewan from 2013 to 2015, and registered on 20 May 2016 (Registration no. 8011 for AAC Y012 and 8012 for AAC Y015), at the Variety Registration Office, Canadian Food Inspection Agency, Ottawa, ON.

\section{Pedigree and Breeding Methods}

AAC Y012 and AAC Y015 tested as L11YL012 and L11YL015, respectively, were derived from the cross PI 406158/Peruano Higuera, made at the AAFC Morden Research and Development 
Balasubramanian et al. - AAC Y012 and AAC Y015 yellow dry bean

Centre, MB in 2006. PI 406158, also referred to as "Peter's Yellow Eye", was obtained from the USDA-ARS, Pullman, WA, USA. PI 406158 had a determinate bush (Type I, Brick and Johnson, 2004) growth habit and was selected as a parent for its early maturity and yellow seed coat colour. Peruano Higuera is a yellow bean cultivar developed and commercially grown in Mexico. Peruano Higuera was derived from the cross Canario Divex 8130/Royal Red made at the International Centre for Tropical Agriculture, Cali, Colombia. Canario Divex 8130 (G 5707) is a yellow bean cultivar from Peru with a determinate bush (Type I) growth habit. Royal Red (G 4450) is a dark red kidney bean cultivar from the USA with a determinate bush (Type I) growth habit. Peruano Higuera is photoperiod sensitive, and therefore, requires a short day length of $12 \mathrm{~h}$ to flower. However, it was selected as a parent for its large seed size (100 seed weight $>55 \mathrm{~g})$ and yellow seed coat colour preferred by consumers in Mexico, a major market for yellow bean produced in Canada. AAC Y012 and AAC Y015 were developed by modified pedigree breeding method. Ten $F_{1}$ plants of the cross were grown in a greenhouse at Morden in winter 2007, and the $F_{2}$ seeds were harvested and grown in a field at Lethbridge and Vauxhall, AB in 2007. The seeds were bulk harvested at both locations and the $\mathrm{F}_{3}$ bulk populations were grown at Lethbridge and Vauxhall in 2008. Single plant selections were made based on early maturity and yellow bean seed traits (size, shape, and colour). In the $\mathrm{F}_{4}$ plant row nursery at both locations in 2009, single plant selections were made again based on early maturity and yellow bean seed traits. Eighteen plants were selected from the $\mathrm{F}_{4}$ nursery in Lethbridge and one plant was selected from the nursery in Vauxhall. Southern Alberta experienced below-average temperatures and above-average precipitation in spring 2010. Due to poor weather, the $F_{5}$ plants were seed increased in a greenhouse at Lethbridge. AAC Y012 and AAC Y015 were tested as L11YL012 and L11YL015 in the wide row $(60 \mathrm{~cm})$ Preliminary $\left(\mathrm{F}_{6}\right)$ Yield Trials with three replications at 
Balasubramanian et al. - AAC Y012 and AAC Y015 yellow dry bean

Lethbridge and two replications at Vauxhall in 2011. AAC Y012 and AAC Y015 were tested in the wide row $(60 \mathrm{~cm})$ Pre-Cooperative $\left(\mathrm{F}_{7}\right)$ Yield Trials with three replications at Lethbridge and Bow Island, AB in 2012. Based on seed yield and quality, lodging resistance, and early maturity, AAC Y012 and AAC Y015 were advanced to the Short Season Wide Row Irrigated Dry Bean Cooperative Registration Trials from 2013 to 2015, which were grown at Lethbridge, Vauxhall and Bow Island, AB and Outlook, SK. The Short Season Wide Row Irrigated Dry Bean Cooperative Registration Trial plots consisted of four rows with a row length of $5 \mathrm{~m}$, and the experimental design was a lattice with four replications. The yellow dry bean cultivar CDC Sol was used as a check cultivar in the Cooperative Registration Trials.

Two hundred pods were randomly selected from AAC Y012 and AAC Y015 plants grown in a seed increase nursery at Vauxhall in 2011. Pods were hand-threshed individually and seeds $\left(\mathrm{F}_{7}\right)$ with size, shape, and colour appropriate for a yellow bean market class were selected. The seeds were grown in a greenhouse at Lethbridge in winter 2012 and the plants were harvested individually. After examining the seed $\left(\mathrm{F}_{8}\right), 63$ progeny-rows of AAC Y012 and 48 progeny rows of AAC Y015 were planted at Twin Falls, Idaho in summer 2012. The progeny rows were bulked and this $\mathrm{F}_{9}$ seed formed the first breeder seed.

\section{Performance}

YIELD: In the Short Season Wide Row Irrigated Dry Bean Cooperative Registration Trials grown at nine station-years, AAC Y012 averaged $2.75 \mathrm{t} \mathrm{ha}^{-1}$ and AAC Y015 averaged $2.61 \mathrm{t} \mathrm{ha}^{-1}$ which were similar to the check cultivar CDC Sol $\left(2.70 \mathrm{t} \mathrm{ha}^{-1}\right)$ (Table 1). Data from the Cooperative Registration Yield Trial at Lethbridge and Vauxhall in 2014 were not included in the statistical 
Balasubramanian et al. - AAC Y012 and AAC Y015 yellow dry bean

analysis due to high CV ( $>20 \%)$, and the plots at Vauxhall in 2015 were destroyed by a hail storm in early-June.

MATURITY: AAC Y012 and AAC Y015 had an average maturity of $102 \mathrm{~d}$ over the 11 stationyears, which was a day later than the check cultivar CDC Sol (Table 1).

SEED WEIGHT: The average seed weight of AAC Y012 over 11 station-years was $41.6 \mathrm{~g} 100$ seeds $^{-1}$, which was significantly lower than CDC Sol (43.2 g). The average seed weight of AAC

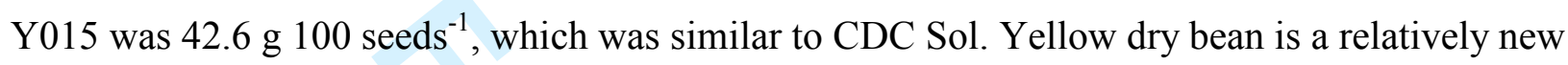
market class which was first commercially produced in Canada in 2009. The seed weight of currently registered yellow bean cultivars including CDC Sol and Myasi $(100$-seed weight $<45$ $\mathrm{g}$ ) is lower compared to the Mexican yellow bean cv. Peruano Higuera (100 seed weight $>55 \mathrm{~g})$, which is considered as the standard for dry seed quality in the yellow bean market class due to its large seed size and bright yellow colour. However, yellow bean seeds with low seed weight produced in Canada have been accepted in the export markets of the USA and Mexico. LODGING: At maturity, AAC Y012 and AAC Y015 had slightly poor lodging resistance compared to CDC Sol (1.5 for AAC Y012, 1.6 for AAC Y015, and 1.3 for CDC Sol) on a scale of $1=$ upright to $5=$ plants with weak stems and prostrate growth (Table 1$)$.

\section{Other Characteristics}

GROwTH HABIT: AAC Y012 and AAC Y015 yellow bean cultivars have a Type I determinate upright bush growth habit similar to CDC Sol. Average plant height of AAC Y012 and AAC Y015 were similar to CDC Sol (37, 38 and $34 \mathrm{~cm}$, respectively).

FLOWER AND SEED: AAC Y012 and AAC Y015 have a pink standard and wing petals, similar to the check cultivar CDC Sol. In addition to seed weight, seed coat colour in an important attribute 
Balasubramanian et al. - AAC Y012 and AAC Y015 yellow dry bean

of yellow bean seed quality as brighter seed coat colour are preferred by consumers compared to seed lots with a dull yellow colour. Seeds of AAC Y012 and AAC Y015 have a brighter yellow colour $\left(\mathrm{b}^{*}=35.7\right.$ for AAC Y012 and 36.8 for AAC Y015) compared to CDC Sol $\left(b^{*}=27.8\right)$ (Table 2). The dry seed coat colour of AAC Y012 and AAC Y015 are visually comparable to Peruano Higuera.

DiSEASE REACTIONS: The white mould disease incidence of AAC Y015 (26\%) was slightly higher than CDC Sol (16\%) (Table 1). The white mould disease severity ratings of all three yellow bean cultivars were similar. AAC Y012 and AAC Y015 are susceptible to races 73 and 105 of anthracnose, caused by Colletotrichum lindemuthianum (Sacc. \& Magnus) Briosi \& Cav.; and common bacterial blight, caused by Xanthomonas axonopodis pv. phaseoli (Smith) Vauterin et al. (Vauterin et al. 1995); syn. X. campestris pv. phaseoli (E.F. Smith) Dye, as is the check cultivar CDC Sol.

Processed SEed Quality: A composite seed sample of AAC Y012, AAC Y015, and the check cultivar CDC Sol harvested at each of the three locations (Lethbridge and Bow Island, AB and Outlook, SK) in 2015 were subjected to both cooking and canning quality tests at the Bean Pilot Plant at AAFC Lethbridge Research and Development Centre. AAC Y012 and AAC Y015 had lower percentages of hard seed after soaking for $16 \mathrm{~h}$ in deionised water at room temperature compared to CDC Sol (Table 3). However, hard seed was not observed after cooking for $20 \mathrm{~min}$ at $97^{\circ} \mathrm{C}$ in any of the three yellow bean cultivars. The texture of AAC Y012 after canning was slightly lower (47.4 $\mathrm{kg}$ force $\left.100 \mathrm{~g} \mathrm{seed}^{-1}\right)$ compared to CDC Sol (51.6 kg force $\left.100 \mathrm{~g} \mathrm{seed}^{-1}\right)$ (Table 3). The b* value (yellow-blue) of AAC Y015 was higher (15.8) compared to CDC Sol (14.5) indicating the seeds retained the yellow seed coat colour during the canning process (Table 2). The $b^{*}$ value of AAC Y012 (15.0) after canning was similar to CDC Sol. AAC Y012 and 
Balasubramanian et al. - AAC Y012 and AAC Y015 yellow dry bean

AAC Y015 were similar to CDC Sol for hydration coefficient, percentage drain weight, matting, and appearance (Table 3).

\section{Maintenance and Distribution of Pedigreed Seed}

Breeder seed of AAC Y012 and AAC Y015 will be maintained by the AAFC Lethbridge Research and Development Centre, Lethbridge, AB. AAC Y012 and AAC Y015 have been released on an exclusive basis for seed production and marketing to Viterra Inc., $2802-5^{\text {th }}$ Avenue North, Lethbridge, AB, T1H 0P1, where pedigreed seed may be purchased.

\section{Acknowledgements}

The financial support provided by Viterra, Alberta Pulse Growers Commission, Alberta Crop Industry Development Fund, Alberta Innovates - Bio Solutions, and AAFC Agri-Science Clusters is gratefully acknowledged. The authors thank C.R. Daniels, T. Reid, G. Kereliuk, and R.S. Erickson at Lethbridge, and W.C. Penner and D.B. Stoesz at Morden for their technical assistance. The authors would also like to thank D.T. Tomasiewicz, D.L. David, and G. Hnatowich at the Canada-Saskatchewan Irrigation Diversification Centre, Outlook, SK for performing the Cooperative Registration Trial.

Brick, M. A. and Johnson, J. J. 2004. Classification, development and varietal performance. Pages 7-13 in H. F. Schwartz, M. A. Brick, R. M. Harveson, and G. D. Franc, eds. Dry bean production and pest management. 2nd ed. Bulletin 562A. Colorado State University, University of Nebraska, Lincoln, NE, and University of Wyoming, Laramie, WY, USA.

Vauterin, L., Hoste, B., Kersters, K. and Swings, J. 1995. Reclassification of Xanthomonas. Internat. J. System. Bacteriol. 45: 472-489. 
Balasubramanian et al. - AAC Y012 and AAC Y015 yellow dry bean

Table 1. Mean of agronomic and disease traits of the yellow bean cultivars AAC Y012 and AAC Y015, and the check cultivar CDC Sol grown in Alberta and Saskatchewan from 2013 to 2015.

\begin{tabular}{|c|c|c|c|c|c|c|}
\hline \multirow[b]{2}{*}{ Cultivar } & \multirow{2}{*}{$\begin{array}{c}\text { Yield } \\
\left(\mathrm{t} \mathrm{ha}^{-1}\right)\end{array}$} & \multirow{2}{*}{$\begin{array}{c}\text { Maturity } \\
\text { (days) }\end{array}$} & \multirow{2}{*}{$\begin{array}{c}\text { Seed weight } \\
\left(\mathrm{g} 100 \text { seeds }^{-1}\right)\end{array}$} & \multirow{2}{*}{$\begin{array}{l}\text { Lodging resistance }^{a} \\
\text { (1-5 scale })\end{array}$} & \multicolumn{2}{|c|}{ White mould $^{b}$} \\
\hline & & & & & Incidence $(\%)$ & Severity $(1-4)$ \\
\hline CDC Sol & 2.70 & 101 & 43.2 & 1.3 & 16 & 1.4 \\
\hline AAC Y012 & 2.75 & 102 & 41.6 & 1.5 & 20 & 1.5 \\
\hline AAC Y015 & 2.61 & 102 & 42.6 & 1.6 & 26 & 1.7 \\
\hline $\operatorname{LSD}_{0.05}^{c}$ & 0.57 & 1 & 1.2 & 0.2 & 7 & 0.4 \\
\hline Station-years & 9 & 11 & 11 & 10 & 3 & 3 \\
\hline
\end{tabular}

${ }^{a}$ Lodging resistance is determined at maturity using a 1 to 5 scale, from $1=$ upright plants, $3=$ partially upright plants to $5=$ plants lodged due to weak stems.

${ }^{b}$ White mould incidence refers to the mean percentage of plants with symptoms in the inoculated disease nursery at Lethbridge from 2012 to 2014 . White mould severity was assessed using a 1 to 4 scale, where $1=$ healthy plants, $2=$ plants have one infected branch or pod, 3 = plants have multiple infected branches or pods, and $4=$ main stem is girdled or plants are dead.

${ }^{c}$ Least significant difference, $P \leq 0.05$, calculated from a pooled error term of all entries common to the respective three years in the Short Season Wide Row Irrigated Dry Bean Cooperative Registration Trial. 
Balasubramanian et al. - AAC Y012 and AAC Y015 yellow dry bean

Table 2. Mean of seed coat colour attributes of yellow bean cultivars AAC Y012 and AAC Y015, and the check cultivar CDC Sol grown in Alberta and Saskatchewan in 2015.

\begin{tabular}{lcccccc}
\hline & \multicolumn{3}{c}{ Dry seed $^{a}$} & \multicolumn{3}{c}{ After canning $^{b}$} \\
\cline { 2 - 7 } Cultivar & $\mathrm{L}^{*}$ & $\mathrm{a}^{*}$ & $\mathrm{~b}^{*}$ & \multicolumn{1}{c}{$\mathrm{L}^{*}$} & \multicolumn{1}{c}{$\mathrm{b}^{*}$} \\
\hline CDC Sol & 65.8 & 1.9 & 27.8 & 55.0 & 7.2 & 14.5 \\
AAC Y012 & 66.8 & 1.2 & 35.7 & 56.2 & 6.2 & 15.0 \\
AAC Y015 & 67.3 & 1.1 & 36.8 & 55.8 & 6.7 & 15.8 \\
LSD $_{0.05}$ & 1.9 & 0.4 & 1.0 & 1.4 & 0.4 & 1.0 \\
\hline
\end{tabular}

${ }^{a}$ Colour of dry bean seed: $\mathrm{L}^{*}, \mathrm{a}^{*}$, and $\mathrm{b}^{*}$ attributes of colour were measured on dry and processed (canned) seed using a CR-410 Chromameter (Konica Minolta Sensing Americas, Inc., Ramsey, NJ, USA). L* indicates "lightness-darkness" with higher values indicate whiteness; $\mathrm{a}^{*}$ indicates "red-green" with positive values indicate redness and negative values indicate greenness; and $\mathrm{b}^{*}$ indicates "yellow-blue" with positive values indicate yellowness and negative values indicate blueness.

${ }^{b}$ One-hundred g of processed bean seed was used to determine colour after canning. 
Balasubramanian et al. - AAC Y012 and AAC Y015 yellow dry bean

Table 3. Mean of cooking and canning quality traits of the yellow bean cultivars AAC Y012 and AAC Y015, and the check cultivar CDC Sol grown in Alberta and Saskatchewan in 2015.

\begin{tabular}{|c|c|c|c|c|c|c|c|c|}
\hline \multirow[b]{2}{*}{ Cultivar } & \multicolumn{2}{|c|}{$\begin{array}{l}\text { Cooking quality - } \\
\text { Hard seed }(\%)^{a}\end{array}$} & \multicolumn{6}{|c|}{ Canning quality } \\
\hline & $\begin{array}{c}\text { After } \\
\text { soaking }\end{array}$ & $\begin{array}{c}\text { After } \\
\text { cooking }\end{array}$ & $\mathrm{HCS}^{b}$ & $\mathrm{HCB}^{c}$ & $\begin{array}{c}\text { Drain } \\
\text { weight }(\%)^{d}\end{array}$ & $\begin{array}{l}\text { Matting } \\
(1 \text { to } 4)^{e}\end{array}$ & $\begin{array}{l}\text { Appearance } \\
(1 \text { to } 4)^{f}\end{array}$ & $\begin{array}{l}\text { Texture }(\mathrm{kg} \\
\text { force) }^{g}\end{array}$ \\
\hline CDC Sol & 12.6 & 0.0 & 2.3 & 2.4 & 53.1 & 1.6 & 1.9 & 51.6 \\
\hline AAC Y012 & 7.4 & 0.0 & 2.3 & 2.4 & 51.7 & 1.4 & 1.5 & 47.4 \\
\hline AAC Y015 & 4.5 & 0.0 & 2.3 & 2.4 & 51.1 & 1.2 & 1.3 & 49.1 \\
\hline $\mathrm{LSD}_{0.05}$ & 2.1 & 0.0 & 0.1 & 0.1 & 2.4 & 0.4 & 0.6 & 3.4 \\
\hline
\end{tabular}

${ }^{a}$ Two hundred seeds from a composite seed sample per genotype per location were soaked in deionised water at room temperature for $16 \mathrm{~h}$ and cooked for $20 \mathrm{~min}$ at $97^{\circ} \mathrm{C}$. Percentage hard seed was determined after soaking and after cooking.

${ }^{b}$ Hydration coefficient after soaking (HCS): Eighty-six grams of yellow bean seed was soaked for $16 \mathrm{~h}$ in deionised water at room temperature. Hydration coefficient after soaking was determined as: seed weight after soaking / weight of dry seed.

${ }^{c}$ Hydration coefficient after blanching (HCB): Soaked seed was blanched for 3 min at $93^{\circ} \mathrm{C}$. Hydration coefficient after blanching was determined as: seed weight after blanching / weight of dry seed.

${ }^{d}$ Drain weight (\%): Bean seeds were processed at $116^{\circ} \mathrm{C}$ for $45 \mathrm{~min}$ in brine. Can content was weighed and the weight of bean seed was determined after washing in tap water on a 8-mesh screen (Tyler series) positioned at a $15^{\circ}$ angle. Percentage drain weight was determined as: (weight of bean seed / weight of can content) $* 100$

${ }^{e}$ Matting (clumping) of seeds was assessed on a 1 to 4 scale, where $1=$ none, $2=$ trace, $3=$ slight and $4=$ moderate.

${ }^{f}$ Appearance of seeds was assessed on a 1 to 4 scale, where $1=$ excellent, $2=$ good, $3=$ acceptable, and $4=$ unacceptable.

${ }^{g}$ Texture (firmness) ( $\mathrm{kg}$ force) was determined by placing $100 \mathrm{~g}$ of washed drained bean in to a standard shear compression cell (CS-1) of Texture Measurement System - Touch (TMS-Touch, Food Technology Corp., Sterling, VA) and shearing them using a load cell of $255 \mathrm{~kg}$-force at a rate of $0.83 \mathrm{~cm} \mathrm{sec}^{-1}$. 